\title{
Machiavelli's people and Shakespeare's prophet: the early modern afterlife of Caius Martius Coriolanus*
}

\author{
Peter Iver Kaufman \\ Professor, George Matthews and Virginia Brinkley Modlin Chair in Leadership Studies, Jepson School of \\ Leadership Studies, University of Richmond, USA
}

\begin{abstract}
Both Machiavelli and Shakespeare were drawn to Livy's and Plutarch's stories of the legendary field commander turned political inept, Caius Martius, who was honored with the name Coriolanus after sacking the city of Corioles. The sixteenth-century 'coriolanists' are usually paired as advocates of participatory regimes and said to have used Coriolanus's virulent opposition to power-sharing in early republican Rome as an occasion to put plebeian interests in a favorable light. This article objects to that characterization, distinguishing Machiavelli's deployment of Coriolanus in his Principe and Discorsi from Shakespeare's depiction of Coriolanus and his critics on stage. The essay that follows puts Machiavelli's and Shakespeare's comments on Caius Martius in the context of the 'factious practices' they deplored in late medieval Italy and Elizabethan and early Stuart England, respectively.
\end{abstract}

Keywords: 'Coriolanus', faction, Livy, Machiavelli, plebeians, Plutarch, republic, Shakespeare, tribunes

Niccolò Machiavelli and his Prince surface in many leadership studies that draw upon the humanities. Il Principe passes as an apology for early modern absolutism yet still prompts lively discussions of modern government and political morality. Its model sovereign is imperious, often cruel, and always controversial in the classroom. The book's fifteenth chapter couples statements expressing two sentiments responsible for Machiavelli's reputation as rogue and realist. The first advised princes to learn not to be good (imparare a potere non buono). Machiavelli conceded that the illusion of being virtuous serves princes well, but dissembling and treachery are more reliable ways to snatch and keep power. So much for the rogue; Machiavelli, the realist, was about results. He prefaced his non buono with promises to steer clear of abstractions and imaginary regimes. He is commonly said to have spawned political science by relying on the concrete, stocking his counsel for sovereigns with examples extracted from antiquity and lessons learned from contemporaries' and from near neighbors' mistakes and successes. He relied, that is, on what was or had been done rather than on the hypothetical or hyped up. To show how (and explain why) effects excused

I thank Professor J. Thomas Wren for his comments on an earlier draft of this essay. And, with abiding friendship and respect, I dedicate it to Tom on the occasion of his retirement from our faculty at the University of Richmond's Jepson School and with appreciation for this journal, an endeavor he and his colleagues have just launched. 
princes whom their tactics accused, he declared that he would go directly to tangible truths (andare drieto alla verità effettuale della cosa). ${ }^{1}$

Despite his reputation for using the expected results or ends to justify princes' meanness, his counsel was more than a brief for cruelty. His less well known Discourses on Livy present a set of insightful reflections on leadership in republics. He turned to the early Roman republic to illustrate the promise and peril of broadly participatory regimes. And one figure, Caius Martius Coriolanus, whose notoriety owes more to Shakespeare than to Machiavelli, gave the latter a chance to explain how effectively people could be mobilized to keep republican governments from capsizing.

But Coriolanus was and still is a controversial figure. Livy and Plutarch pieced together from sources, now lost, his reputation for exceptional valor, especially during the siege and sack of the city of Corioli. Caius Martius's superior added 'Coriolanus' to his name, commemorating the victory and commending its principal architect. Patricians in Rome were delighted; plebeians were not. As Caius Martius, Coriolanus opposed empowering them. As Coriolanus, he refused to defer to them, and deference was necessary if, as patricians in the senate expected, their nominee was to become one of Rome's two consuls.

But Coriolanus's disdain for commoners made them resentful. He was vilified, tried on trumped-up charges, nearly executed, and banished from Rome. As the story came to Livy and Plutarch and, from them, to Machiavelli and Shakespeare, Coriolanus was moved by plebeian ingratitude to join and lead Rome's enemies to the very gates of the city he had served. Rome was saved, in large part, by his mother's pleas. But sparing those who had evicted him meant betraying their (and his former) enemies who subsequently befriended and trusted him. They repaid his betrayal and killed him.

Coriolanus's fate would have made for just another interesting, generally unverifiable story from archaic Rome, had interpreters not drawn from his misfortune different implications for the conduct of leadership in a republic or for the virtue or viciousness of republican regimes. This paper juxtaposes two different interpretations - the first, Machiavelli's, was written early in the sixteenth century; the second, Shakespeare's, nearly a century later - to discuss their reasons for repossessing and redeploying Coriolanus. I want to consider how and why Machiavelli, the early modern diplomat, sifted the origins of the Roman republic to underscore the importance of developing adequate means to express ordinary citizens' resentments and, thereby, to temper the tyranny he sometimes seemed to sanction in his Prince. We also want to learn why Shakespeare, the early modern dramatist, doubted the value of republican initiatives. Undiplomatic Coriolanus was an antagonist in the diplomat's Discorsi. His abrasiveness stirred popular opposition, which, when properly channeled, demonstrated the effectiveness of the plebeians' and of their tribunes' discretion. But, as the playwright's protagonist, Coriolanus was contemptuous of plebeians and their tribunes. Coriolanus, the play, ends badly for him. But his contempt prompts us to discuss dilemmas still facing leadership studies that assess relationships between leaders and

1. Citations refer to chapters in Machiavelli's Prince (Il Principe), for which consult http:// www.classicitaliani.it. As noted, its advice on learning to be deceitful and its attachments to the historical and practical are yoked in chapter 15. Principe, chapter 18, considers the value of simulated virtue. Machiavelli's Discourses on Livy's Ab urbe condita libri, his history of Rome (Discorsi sula prima deca di Tito Livio), can be accessed at the same website. Citations here refer to book, chapter, and section. Discorsi, 1.9, 2 suggests that a practice's effects frequently excuse a practitioner's apparent wickedness, accusandolo il fatto, il effetto lo scusi. Here, translations from Machiavelli and, later, from Livy's Ab urbe condita, accessed at www.thelatinlibrary.com, are mine. 
the led in republican governments. And his contempt will eventually tempt us to enroll him among other disgraced yet discerning prophets in the history of political dissent.

Machiavelli hunted for tangible truths about republican Rome in Titus Livy's history, which circulated in the first century CE. It siphoned information from predecessors who relied on legend and subsequently lost sources to rehearse what is now called the city's 'conflict of the orders,' a struggle that supposedly attended the transition from regal to consular government in the late sixth and early fifth centuries, BCE. Reportedly, at the time, plebeians and patricians were at odds - the former extorting concessions from a senatorial elite. Livy and his sources, however, are now said to have exaggerated the plebeians' influence and, 'afflicted with numerous anachronisms,' cannot be used to reconstruct the socioeconomic texture of archaic Rome. As for 'the conflict of the orders,' which Machiavelli considered essential for good government, its extent and character during the first decades of the republic are impossible to determine with confidence. Some scholars suggest that Coriolanus was then confronting and criticizing an assortment of near destitute urban artisans and tenant farmers, a diverse, economically disadvantaged plebeian 'front' that seceded or went on strike to acquire political representation and a larger share of available wealth. But the apparent success of their efforts may indicate that they were led by affluent landowners and citizen soldiers able to afford the equipment necessary for military services and eager to check the patricians' power. ${ }^{2}$ And, as Emilio Gabba notices, ambiguities and inaccuracies not only skewed what Livy wrote about the plebeians in the young republic but also affected the way his sources defined patricians. Gabba thinks the 'codification' of the Roman aristocracy occurred long after Coriolanus and the elites would have encountered commoners' agitation and their tribunes' demands. Hence, historians ought to approach all Roman sources for that stretch very cautiously, molto prudenti. ${ }^{3}$

Well into the twentieth century, however, most scholars accepted what Livy wrote about the early republic as 'highly reliable.' 4 So we should not expect Machiavelli to have been unduly skeptical. Besides, Livy's story of Coriolanus's insolence and of the plebeians' reactions was too good to be untrue, which is to say that it fit Machiavelli's preconceptions and purposes. Livy had retrieved the political tensions that led, through the Roman tribunes' robust interventions, to the city's defensible verdict against Coriolanus - and to the restoration of order in Rome. In effect, Livy substantiated Machiavelli's claims that mistrust among the elites enabled commoners and their representatives to stabilize republican government. No wonder Machiavelli 'made the history of Titus Livy his Bible. ${ }^{5}$

2. See essays by Kurt Raaflaub, Timothy J. Cornell, Jean-Claude Richard and Arnaldo Momigliano (2005), Social Struggles in Archaic Rome, New Perspectives on the Conflict of the Orders, in Kurt Raaflaub (ed.), Oxford: Blackwell, for soldiers and the secession, see Raaflaub's 'From Protection and Defense to Offense and Participation: Stages in the Conflict of the Orders,' in that volume, particularly pp. 196-197 and 208-209; Jean-Claude Richard's (1985) 'Sur Trois Problèmes du Premier Âge Républicain,' Mélanges de l'Ecole Française de Rome, Antiquité, 97, pp. 772-774, implies that soldiers present among the plebeians joined patricians' dissatisfied clients, protesting the distribution of the spoils of war. For anachronisms, see Kaj Sandberg (1993), 'The Concilium Plebis as a Legislative Body during the Republic,' in Jyri Vaahtera (ed.), Senatus Populusque Romanus, Helsinki: Institutum Romanum Finlandiae, pp. 74-75.

3. Emilio Gabba (2000), Roma Arcaica: Storia e Storiografia: Nuove Ricerche sul Conflitto fra Patrizi e Plebei in Roma Arcaica, Rome: Edizioni di Storia e Letteratura, pp. 252-255.

4. Antonio Guarino (1975), La Rivoluzione della Plebe, Naples: Liguori, p. 194.

5. Harvey C. Mansfield (1996), Machiavelli's Virtue, Chicago: The University of Chicago Press, p. 78. 
And that 'bible' demonized Coriolanus. The context was significant. Livy explained that quarrels between plebeians and patricians were resolved after Rome's last king had been deposed and when commoners were granted the right to select tribunes to protect their interests. But crop failures in local fields, the arrival of corn from patricians' Sicilian estates, and prices charged by the patricians prompted Rome's commoners to demand price controls. According to Livy, Coriolanus proposed to use the crisis to cancel the concessions that, in his estimation, the plebeians had extorted from the senate. If they wanted to return to the prices that pertained when corn was plentiful, commoners, he submitted, must relinquish their newly acquired prerogatives and return full authority to the patricians. ${ }^{6}$

Coriolanus's blunt ultimatum and exploitation of the famine is thrown into greater relief in Livy's story by his description of another patrician's tact and tactics; his Menenius Agrippa reassured commoners that the patrician senate and moneyed interests it represented were vitally concerned with plebeians' wellbeing. The elites were comparable to a body's belly, Menenius explained; although more conspicuously industrious members of the body politic may suspect that the stationary stomach was idle, it was not; the belly, much as Rome's affluent elite, was busy, wisely distributing nourishment. Livy mentions that the commoners were fond of Menenius; however, his analogy was not an unqualified success. Plebeians' anger somewhat abated, yet they consented only to negotiations, the result of which were the concessions that Coriolanus deplored. ${ }^{7}$

Livy's sympathies are with the commoners, and that obviously appealed to Machiavelli. They had protested peacefully. They forced the senate to negotiate by leaving the city, settling provisionally several miles away. They gave no other provocation, yet the suspense, Livy says, was paralysing. Plebeians, who had not 'seceded' and were left in Rome, were frightened that they might become targets of the city's patricians. Plebeians and patricians alike were tormented by the prospect that a Rome so divided, fear-filled, and, in effect, immobilized, might fall prey to its enemies. The senate concluded that reconciliation was required for Rome's defense. Historian Christopher Mackay claims that the senate's next steps - allowing commoners to elect tribunes marked 'the beginning of the corporate organization of the plebs as a kind of state within the state. ${ }^{8}$ But, as we learned, many of Mackay's colleagues are unsure that sparring partners in early fifth-century Rome should be identified with relatively homogenous 'orders' or 'states.' Machiavelli, however, had no such reservations. He saw a new and desirable order emerging from 'the conflict of the orders' in archaic Rome. Livy seems to have been far less sanguine about the new order, although Thomas Baier thinks he was disposed to award 'ultimate authority' to the vox populi, if commoners could achieve sufficient unanimity to speak meaningfully with a single voice. $^{9}$

6. Livy, Ab Urbe Condita 2.34 (see note 1).

7. Livy, Ab Urbe Condita 2.32-33.

8. But Christopher S. Mackay (2004), Ancient Rome: A Military and Political History, Cambridge: Cambridge University Press, pp. 32-36, does not think the election of the first tribunes was part of a stalwartly, stridently anti-patrician strategy.

9. Thomas Baier (2003), 'Ein Kommentar zum Rechtsdenken der ausgehenden Republik,' in Ulrich Eigler, Ulrich Gotter, Nino Luraghi and Uwe Walter (eds), Formen Römischer Geschichtsschreibung von den Anfängen bis Livius, Darmstadt: Wissenschaftliche Buchgesellschaft, p. 247: 'Die vox populi hat bei Livius, wenn sie so einmütig geäussert wird, stets höchste Autorität.' 
Livy's sympathies are not easy to locate. Janet Chaplin seems sensible maintaining that his 'distillation of history into exempla' was meant to chart 'a way out' of the difficulties he and his first readers were experiencing. ${ }^{10}$ Still, in his account of the emerging republic, Livy seems to use Coriolanus as an example of how to anger commoners and create difficulties, giving Machiavelli a chance to use Coriolanus as an occasion, not an example - an occasion to show how well the early Roman republican government worked. Coriolanus, as we just discovered, was unpopular for having proposed that grain be withheld until the plebeians were prepared to give up the authority they and their tribunes had lately acquired. Predictably, the plebeians were furious; had they rioted, Coriolanus would have been slaughtered, patricians would have taken precautions for self-defense, partisans of both sides, driven by fear or indignation, would have turned an incident into a feud, destabilizing Rome's new republic. ${ }^{11}$ But tribunes, wasting no time, Machiavelli emphasized, summoned Coriolanus to argue his case, answer objections, and accept punishment. Unlike officials in the Republic of Florence, who provided their citizens no forum in which to vent their anger (sfogare), the tribunes in Rome found an effective way to spare their city the turmoil suffered by Machiavelli's. $^{12}$

Livy's Coriolanus was an exemplary soldier. He and a small squadron not only repelled a Volscian attack but carried the battle to his enemies, capturing the city of Corioli - and capturing, for Caius Martius, his cognomen. ${ }^{13}$ Later, during a crisis precipitated by the senate's concessions and brought to a boil by Coriolanus's incivility, he was banished from Rome, joined the Volsces, all but supplanted their commander, and led their troops to avenge their previous humiliation - at his hands - and to settle his score against those who banished him. ${ }^{14}$ Neither Machiavelli nor Livy appears to have been interested in the mechanics of the military maneuvers, yet both noticed that Coriolanus shrewdly sought to intensify 'the conflict of the orders' by plundering commoners' properties in the countryside and leaving those of the patricians untouched. Machiavelli admired the strategy. Commanders should sow dissension among enemies, he averred, coupling Hannibal with Coriolanus, two adepts waging psychological as well as bloody wars. ${ }^{15}$ Coriolanus clearly met Livy's expectations that field commanders lead by example ( pugnando quam adhortando); belligerent action rather than talk inspired soldiers whose advance, in one of Livy's stories, was suddenly stalled by the death of a valued comrade. ${ }^{16}$ Livy's Coriolanus - exceptional at action, excellent at soldiering - was an awkward talker, as he was in Petrarch's sketch and would be in Shakespeare's tragedy, 'a brilliant general lost in the tricks of politics.' ${ }^{17}$

10. Janet D. Chaplin (2000), Livy's Exemplary History, Oxford: Oxford University Press, pp. 198-201.

11. Machiavelli, Discorsi 1.7, 1-2. John P. McCormick (1993), 'Addressing the Political Exception: Machiavelli's “Accidents" and the Mixed Regime,' The American Political Science Review, 87, pp. 892-895, believes Machiavelli feared that mob action would start a "chain reaction' with 'devastating consequences' for government, for which, also see McCormick's (2011) Machiavellian Democracy, Cambridge: Cambridge University Press, pp. 68-69.

12. Machiavelli, Discorsi 1.7, 3-4.

13. Livy, Ab Urbe Condita 2.33.

14. Livy, Ab Urbe Condita 2.39.

15. Machiavelli, Dell'arte della Guerra 6, accessed at http://www.bibliotecaitaliana.it.

16. Livy, Ab Urbe Condita 2.46.

17. Christopher Pelling (2002), Plutarch and History, London: Duckworth, p. 240. Whether Pelling's observation is accurate with respect to the historical Caius Martius is impossible to 
That observation, as it applies to Petrarch's Coriolanus, is Christopher Pelling's, with whom Machiavelli would have disagreed. The new regime in Rome, having expelled the city's king and just begun to program an emerging republic, was neither tricky nor treacherous. It was heading in the right direction. Two consuls were elected annually. Candidates were candid, not deceptive. Leaders were virtuous and resourceful. ${ }^{18}$ When patricians threatened to deprive the plebeians of their prerogatives - as Coriolanus did - tribunes protected both, and, doing so, they preserved civility in the city as well as citizens' rights. Machiavelli was heartened by the results attributing everything good about Roman government to the plebeians' discontent and tribunes' interventions. ${ }^{19}$ His enthusiasm was undiminished by what Livy and others reported about the senate's ability to frustrate tribunes during the fifth century. ${ }^{20} \mathrm{He}$ saw no abyss open between the plebeians and patricians in the immediate aftermath of Rome's regal period. What mattered to him was that tribunes had stopped Coriolanus's bid to compel commoners to surrender their political advantages and status and that tribunes continued determinedly to preside over what John McCormick now imagines to have been a 'procedurally formalized popular discussion of and judgment over ... the lives of the grandi.' ${ }^{21}$ Machiavelli admitted that plebeians occasionally became overbearing, yet the greater danger, he continued, originated with the patricians, whose youth looked for chances to reassert their caste's political dominance. Even parents acknowledged that their children often were 'too savage,' nearly toppling the tribunate. But the office had survived for centuries in Rome, and Machiavelli lamented that fifteenth- and early sixteenth-century Florence had nothing comparable. ${ }^{22}$ Archaic Rome's tribunes, agitating 'against ambition and insolence,' he claimed, constantly revived republican virtues. ${ }^{23}$

Plebeians were ambitious, susceptible to temptations to improve their lot, economically and politically, but, conceding as much, Machiavelli nevertheless trusted that they were a safer bet than their patrician neighbors to be discerning and prudent. ${ }^{24}$ The early modern Venetians, having deposited power with patricians, were less well governed than the Romans who handed over considerable authority to the plebeians (nelle mani della plebe). ${ }^{25}$ The Romans had discovered that commoners were unlikely to be driven by a desire to dominate. Non essere dominati; liberation, not domination,

determine. The characterization fits equally well the Coriolanus constructed by Livy and Machiavelli - with the qualification noted in the text - and especially well the Coriolanus conveyed by Plutarch and Shakespeare.

18. Machiavelli, Discorsi 1.20.

19. Machiavelli, Discorsi 1.2, 7.

20. For which development, see Jean-Claude Richard (1985), 'Sur Trois Problèmes du Premier Âge Républicain,' Mélanges de l'Ecole Française de Rome, Antiquité, 97, 781-782.

21. John P. McCormick (2011), Machiavellian Democracy, Cambridge: Cambridge University Press, p. 72. With plebeians' backing, then, the tribunes allegedly checked the ambition of the grandi (or nobility), which would otherwise have corrupted the republic soon after its onset. See Machiavelli, Discorsi 3.11, 1.

22. Machiavelli, Discorsi 1.46 for the savagery and 1.49 for the lament. McCormick (2001), 'Machiavellian Democracy: Controlling Elites with Ferocious Populism,' The American Political Science Review, 95, 297-303 compares patrician and plebeian overreaching, stipulating that the latter, unlike the former, never sought to dominate the government. McCormick, Machiavellian Democracy, p. 61 adds that Machiavelli's criticism of patrician ambition was 'fairly faithful' to Livy, whereas his 'fulsome praise of the people and apologetic approach to their mistakes are departures from Livy's account.'

23. Machiavelli, Discorsi 3.1, 3.

24. Machiavelli, Discorsi 1.58, 3.

25. Machiavelli, Discorsi 1.5, 1. 
was the plebeians' foremost concern, and, for Machiavelli, that priority was the factor that would keep the fabric of republics from being ripped by factions and greed. ${ }^{26}$ 'The people' proved more effective than princes. 'The people' were possessed of greater virtù. ${ }^{27}$ When necessary, they asserted their authority, although never arrogantly (né mai dominò superbamente). ${ }^{28}$ Coriolanus's contempt for them, notwithstanding his exceptional and exemplary lack of ambition, was enough to condemn him, to rally Livy's and Petrarch's plebeians as well as Machiavelli against him. ${ }^{29}$

Here, Machiavelli was staking out an anomalous, if not also an awkward, position. To be sure, there was no sixteenth-century groundswell of opinion favoring Coriolanus, but Francesco Guicciardini, for one, suggested political tensions were unhealthy, that governments galloped toward disaster when influential theorists countenanced discord between the multitude and the moguls. Laudare le disunione, to praise friction was ludicrous. ${ }^{30}$ Studying late medieval Italy, Machiavelli probably agreed. He deplored the sectarian spirit among early modern patricians. ${ }^{31}$ The case can be made that he was hunting for a leader - in John Najemy's terms, for a 'redeemer-reformer' - to reformulate laws and revive respect for republican virtù in Italy. ${ }^{32}$ Coriolanus was as far as one could be from becoming a model for Machiavelli's 'messiah.'

Few if any adaptations or interpretations of Shakespeare's Coriolanus cast the protagonist as a redeemer or reformer. But the play's plebeians and emergent Roman

26. Machiavelli, Discorsi 1.5, 2 and 1.5, 4, which predicts the infection, assuming that plebeians might be tempted to avenge themselves by despoiling patricians who despoiled them: 'che gli loro scorretti e ambiziosi portamenti accedano, ne' petti di chi non possiede, voglia di possedere o per vendicarsi contro di loro spogliandoli, o per potere ancora loro entrare in quelle richezza e in quelli onore che veggono essere male usati degli altri.'

27. Machiavelli, Discorsi 1.58, 4.

28. Machiavelli, Discorsi 1.58, 2.

29. Mikael Hörnquist (2004), Machiavelli and Empire, Cambridge: Cambridge University Press, p. 197. Shakespeare used Thomas North's translation of Plutarch's Life of Caius Martius Coriolanus, which states that the protagonist endeavored 'to take the soveraine authoritie out of the peoples' handes,' but only to restore it to the senate; The Lives of the Noble Grecians and Romanes (London, 1579), p. 246.

30. Compare Machiavelli, Discorsi 1.4 with Guicciardini, Considerazione intorno ai 'Discorsi' del Machiavelli, 1.4, in Guicciardini (1933), Opere, vol. 8, Roberto Palmarocchi (ed.), Bari: Laterza, pp. 10-11.

31. Machiavelli, Istorie Fiorentine 3.4: Si Vivea in Sospetto Grandissimo e Temevasi per Ciascuno Ogni Rovina. The Istorie was and is accessed at http://www.bibliotecaitaliani.it. It does not repeat the claim Machiavelli's Discorsi made, that tension between plebeians and patricians was what historian Gisela Bock calls 'the dynamic force for expansion and empire'; 'Civil Discord in Machiavelli's Istorie Fiorentine,' Machiavelli and Republicanism, Cambridge: Cambridge University Press, 1993, p. 201. Indeed, the Istorie can be read as an appeal to 'repress strife'; see Alfredo Bonadeo's (1970) still valuable 'The Role of the People in the Works and Times of Machiavelli,' Bibliotheque d'Humanisme et Renaissance, 32, 368.

32. Machiavelli, Istorie 4.1. At precisely this point in the narrative, however, Machiavelli echoes criticism offered by Plutarch's Coriolanus (soon to be emphatically reiterated by Shakespeare's), accusing populist officials of calling for liberty while advocating license (licenza) that imperils social order. John M. Najemy's (2010) 'Society, Class, and State in Machiavelli's Discourses on Livy,' in Najemy (ed.), The Cambridge Companion to Machiavelli, Cambridge: Cambridge University Press, pp. 96-102, suggests Machiavelli often formulated counsel to those 'who deserve to be princes' while doubting their willingness to quicken the pace of reform and redistribute power. Maurizio Viroli, 'Machiavelli and the Republican Idea of Politics,' Machiavelli and Republicanism, p. 171, detects fewer doubts; John McCormick, Machiavellian Democracy, pp. 35-43, finds none, asserting that Machiavelli hoped to win 
republicanism often get good press. At best, Coriolanus comes across as morally ambiguous; at worst, a crude, impudent bigot. Even when performances understate what social reformers consider the play's reformist or populist sympathies, Coriolanus is not credited as a perceptive critic. ${ }^{33}$ His criticism, however, is relevant to Machiavelli's trust in political tension. Could Shakespeare have known of it? He was an avid reader, but Machiavelli's Discorsi did not appear in English until 1663. Historians have argued that 'Machiavellian approaches' were influential during the decades before Shakespeare composed Coriolanus, but the term 'approaches' is usually not pinned to specific themes. After his abortive coup, Robert Devereaux, earl of Essex, was associated with Machiavelli by enemies who variously emphasized his belligerence, scurrility, and social radicalism, yet the accusations leveled before and after his execution in 1601 cannot convincingly be connected with either Machiavelli's republican sentiments or Shakespeare's play that was first performed 7 or 8 years later. ${ }^{34}$ To the extent that Machiavelli's fondness for early republican Rome was 'translated' in late Elizabethan and early Stuart England as a populist manifesto, playwrights could have drawn on those 'Machiavellian approaches' to buttress their briefs for commoners' interests. Indeed, Shakespeare and Machiavelli have been paired as advocates of participatory regimes, and the implication is that Coriolanus, the character, was an occasion for each to put plebeian interests in a favorable light. ${ }^{35}$ To me, this coupling is ill-conceived.

Although literary historian Anne Barton proposes a populist interpretation of the play, she still contends that Shakespeare's Coriolanus repudiates Machiavelli's positive spin on the tension or 'struggle' between patricians and plebeians. ${ }^{36}$ And she has good cause to say so, for the protagonist explicitly complains that "when two authorities are up, neither supreme' peace and calm give way to conflict and confusion; plebeian 'crows' 'peck the [patrician] eagles'; insults and partisan bickering replace serious deliberation. 'General ignorance' turns political conversations from

over patricians Cosimo Rucellai and Zanobi Buondelmonti, the Discorsi's dedicatees, convincing them of 'the honest and decent rather than insolent and licentious nature of the people' so that the two would rally support for 'a more popularly participatory republic' in Florence.

33. For example, see Martin Brunkhorst (1973), Shakespeare's 'Coriolanus' in deutscher Bearbeitung: Sieben Beispiele zum Literarästhetischen Problem der Umsetzung und Vermittlung Shakespeares, Berlin: De Gruyter, pp. 106-107, 170-171 and John Ripley (1998), Coriolanus on Stage in England and America, 1609-1994, London: Associated University Presses, pp. 212-213.

34. But see Victoria Kahn (1994), Machiavellian Rhetoric: From the Counter-Reformation to Milton Princeton: Princeton University Press: pp. 115-116, 121-124 and Hugh Grady (2002), Shakespeare, Machiavelli, and Montaigne: Power and Subjectivity from 'Richard II' to 'Hamlet', Oxford: Oxford University Press, pp. 38-41.

35. Anne Barton (1994), Essays, Mainly Shakespearean, Cambridge: Cambridge University Press, pp. 159-160, arguing against Clifford Chalmers Huffman's claims that Coriolanus was an apology for Jacobean absolutism, for which see Huffman's (1971) 'Coriolanus' in Context, Lewisburg, Pennsylvania: Bucknell University Press, particularly pp. 137, 163-170, and 221-222 but also Brents Stirling's (1949) still valuable study of Shakespeare's preference for absolutism to 'the climate of apprehension' created by pressure for participatory regimes, The Populace in Shakespeare, New York: Columbia University Press, pp. 120, 151 and 175. Annabel Patterson (1989), Shakespeare and the Popular Voice, Oxford: Blackwell, pp. 120-146 is the most vigorously argued dissent. Warren Chernaik's (2011) Myth of Rome in Shakespeare and his Contemporaries, Cambridge: Cambridge University Press, pp. 181-182 mentions the persistence of criticism of Coriolanus, 'sympathetic to the plebeians.'

36. Barton, Essays, p. 149. 
'real necessities' to a scramble of trivial pursuits, which Coriolanus calls 'unstable slightness.' 37

'General ignorance'? Machiavelli's commoners are so shrewd that they are hardly ever deceived (quasi mai s'inganni). ${ }^{38}$ The political intelligence, ignorance, and shrewdness of any population, of course, are eminently debatable. As one of Shakespeare's characters in Coriolanus says, 'our virtues lie in the interpretation of the time,' and interpretations of the time, even at that time, varied. ${ }^{39}$ Those in the streets responsible for the so-called 'Arab Spring' have been lionized as courageous, liberal paladins of political freedom and simultaneously vilified as rabid Islamists and terrorists. ${ }^{40}$ Likewise in sixteenth-century England, the authorities disagreed about commoners' political intelligence, steadfastness, and virtue. Commoners' competence was an issue in the $1540 \mathrm{~s}$ - and again in the $1570 \mathrm{~s}$ - as the religiously reformed debated the role of the laity in parish government. Tudor magistrates and ministers encountered lay refugees from the Continent who were accustomed to broadly participatory parish regimes. They hired and fired pastors. A few English church officials, including Archbishop Thomas Cranmer, were intrigued by that arrangement, but their fascination with the polities of those 'stranger churches' led to no innovative, democratic practices. ${ }^{41}$ The English laity played a prominent part sustaining worship services during Queen Elizabeth's first years, after many Catholic priests were dismissed and while diocesan authorities sought religiously reformed replacements, but lay lectors retired - as ordered - as soon as replacements were found. ${ }^{42}$ The subject of popular participation resurfaced thereafter at Cambridge, in discussions of church discipline. William Fulke introduced the idea that all people affected by decisions ought to have some say in sifting them (quod omnes tangit, ab omnibus debet), but that 'ought' was unpopular among the influential. ${ }^{43}$

37. For Shakespeare's Coriolanus, I cite the second signet edition of the 1623 text, the first folio (New York: Signet, 2002) by act, scene, and lines; hence, in this instance, 3.1, 109-110, 138-139, and 146-147.

38. Machiavelli, Discorsi 3.34, 4.

39. Shakespeare, Coriolanus 4.7, 49-50.

40. Compare Marc Lynch (2012), The Arab Uprising, New York: Perseus, with John R. Bradley (2012), After the Arab Spring, London: Palgrave Macmillan.

41. Peter Iver Kaufman (2004), Thinking of the Laity in Late Tudor England, Notre Dame: University of Notre Dame Press, pp. 41-47, 125-126. For John Calvin's sentiments on lay and local leadership, see Haro Hopfl (1982), The Christian Polity of John Calvin, Cambridge: Cambridge University Press, pp. 110-112.

42. British Library, Additional MS. 19398, fol. 59.

43. British Library, Cotton MS. Titus C VI, fols. 19v-22r. Many of the 'influential,' scholars now stress, had an interest in having their say in their realm's rule. Historians excavating that interest call England a 'monarchical republic' and locate what we might call lobbying efforts among some outspoken bishops and courtiers to secure Elizabeth's agreement to fulfill what they deemed her duty. In that connection, see Patrick Collinson's (1994) seminal study of quasi republican ideas in his Elizabethan Essays, London: Hambledon, pp. 31-56 and the papers collected in The Monarchical Republic of Early Modern England: Essays in Response to Patrick Collinson, John F. McDiarmid (ed.), Aldershot: Ashgate, 2007. Also consult Rosamund Oates's (2012) 'Puritans and the Monarchical Republic: Conformity and Conflict in the Elizabethan Church,' English Historical Review, 127, 819-843, which reconfirms that 'a republican instinct existed within the monarchical state' (p. 820), but which also makes it clear, by omission, that leaders attracted to quasi-republican ideas were unconcerned with commoners' participation, which Fulke advocated (omnes ... omnibus). 
When Shakespeare was still in Stratford-upon-Avon in the 1580s, and into the 1590s when he was settling in London, discussions of popular participation in policymaking were generally contained within discussions of church staffing and liturgy. What risks would attach if congregational decisions required commoners' consent? ${ }^{44}$ Would ordinary people recognize the extraordinary gifts needed to manage colleagues and crises? Hugh Grady suggests Shakespeare's Roman plays, including Coriolanus, pondered the problems posed by putting 'great' leaders 'in a popular political context. ${ }^{45}$ Perhaps Livy and Plutarch sniffed around those issues as well. An early Elizabethan admirer of the former, William Painter, thought that Livy had emphasized the intolerance of the mob, which would have torn Coriolanus 'in pieces,' had the tribunes not intervened to save him. ${ }^{46}$

'Downe must the nobilitie goe'; Matthew Sutcliffe, dean of Exeter Cathedral, issued his warning, predicting what would happen to 'the great,' if government of the local churches were entrusted to ordinary congregants. He evoked the disturbances on the Continent during the 1530s that followed (and, he alleged, had been occasioned by) the religious radicals' experiments with participatory parish regimes. In 1590, when Sutcliffe published his warning, England's elites had some - but small - reason to fear the fate that, according to Painter, awaited Coriolanus, inasmuch as at least one dissident, who wanted to cut the hedges that the landed gentry planted to enclose arable land (keeping commoners and their livestock out), proposed 'cutting down [the] gentlemen' as well. ${ }^{47}$

But Coriolanus is politically imprecise. Hugh Grady counts it as one of Shakespeare's two 'world-weary' plays. It does not consider politics to be 'an invigorating positive force,' Grady says, yet he seems incorrect when he characterizes the play's and playwright's take on archaic Rome's and on early modern England's politics as 'amoral' rather than immoral. The protagonist's opposition to the early republic is, after all, near fanatical. ${ }^{48}$ Disingenuously, tribunes shift the blame onto him. They may seem, at first, to be justified calling him self-absorbed, 'insolent, o'ercome with

44. For example, A Briefe and Plaine Declaration concerning the desires of those faithful ministers that have and do seeke for the discipline and reformation of the Church of England (London, 1584), pp. 106-107, on congregational consent. The authorship of Briefe and Plaine has never been settled with certainty. William Fulke, who favored a broadly participatory parish regime during the Cambridge debate, is one of the leading candidates. Elizabethan puritanism's most systematic theologians, Dudley Fenner, is the other.

45. Grady, Shakespeare, p. 45.

46. William Painter (1566), The Palace of Pleasure Beautified, Adorned, and Well Furnished with Pleasaunt Histories, London: Henry Dedham, fol. C2r.

47. The dissident's threat is quoted in John Walter's (1985) 'A Rising of the People? The Oxfordshire Rising of 1596,' Past and Present, 107, p. 101. Economic hardships drove commoners to agitate for relief, so much so that Chris Fitter (2000), in 'The Quarrel is between our Masters and us, their Men: Romeo and Juliet, Dearth, and the London Riots,' English Literary Renaissance, 30, 154-183, seems justified locating an 'epidemic of disorder' in the 1590s. And we should not forget that Shakespeare's Coriolanus was first staged only a few years after Guy Fawkes was discovered with nearly forty barrels of gunpowder beneath the chamber where the House of Lords, King James, and his son and heir were scheduled to assemble. Only a handful of conspirators was involved in what became known as the 'powder plot,' but fears that commoners' dissatisfaction was widespread and volatile prompted James's Council to contemplate precautions, for which see Conrad Russell (2011), King James VI and I and his English Parliaments, Oxford: Oxford University Press, p. 47. For Sutcliffe's (1590) mock valediction, ; 'downe ... goe,' consult his Treatise of Ecclesiastical Discipline, London: Bishop and Newberie, pp. 186-187. 48. Compare Grady, Shakespeare, p. 47. 
pride, ambitious past all thinking, self-loving. ${ }^{49}$ But playgoers know that Coriolanus was not after power. Nominated consul by the senate, he nonetheless disdained its ritual celebration of his heroism. He left the senate's chamber instead of staying to hear his 'nothings monstered' in a colleague's speech. ${ }^{50} \mathrm{He}$ lacked tact and charm yet seemed genuinely humble. He only reluctantly agreed to display his wounds in the market to rally popular support for the nomination, then rapidly repented turning his scars into a sales pitch. His mother and Menenius, his mentor, would have had him stoop to conquer - that is, to win the plebeians' affection - but he held that pose poorly and for only a short time. ${ }^{51}$ 'Deficiencies' of that sort have been tabulated by historian James Kuzner, who relates them to the play's position on political pageantry, and specifically to its protagonist's objections to republican politics. Kuzner and others underscore the obvious, that Coriolanus 'stand[s] outside the social compact,' but Kuzner most emphatically argues that Shakespeare has his man reject the 'state's controlling fictions,' rituals, and rhetoric, because they, in effect, take away subjects' voices even as they pretend to take them seriously. Coriolanus will not conform to expectations. He will not be 'made meaningful.' 'Acknowledged agency, of which the people seem so covetous,' says Kuzner, is, for Coriolanus, inauthentic. ${ }^{52}$

We cannot confidently infer what Shakespeare thought about personal authenticity from his Coriolanus's transparency and impetuosity. But we may say with certainty that protagonist (and possibly the playwright) would not have endorsed Machiavelli's classification of citizens' street demonstrations and secession, which forced patricians' concessions as bargaining tactics that stabilized the government. ${ }^{53}$ In Shakespeare's play, the tribunes did all the bargaining for the people, inciting otherwise agreeable citizens to rebellion to increase the tribunes' leverage with the senate. Coriolanus as consul, they said, would make citizens 'of no more voice than dogs that are often beat for barking. ${ }^{54}$ But, in effect, and certainly in the end, the tribunes, not Coriolanus, steal the commoners' voices. True, the latter regretted the senate's concessions that created the tribunes, but those tribunes, Brutus and Sicinius, take liberties with the protagonist's impatience with plebeians' demands, turning it into something comprehensively misanthropic - and turning him into the people's 'fixed enemy. ${ }^{55}$ Historian John Roe's observation is on the mark: Shakespeare's Coriolanus 'makes popular, conspiratorial Machiavels of the tribunes, whereas Machiavelli sees them as men of principle, whose disinterested application of the law' gets the new republic off to a good start. ${ }^{56}$

49. Shakespeare, Coriolanus, 4.6, 30-32.

50. Shakespeare, Coriolanus 2.2, 78.

51. Shakespeare, Coriolanus 2.3, 104-105.

52. James Kuzner (2007), 'Unbuilding the City: Coriolanus and the Birth of Republican Rome,' Shakespeare Quarterly, 58, 184-185, 191-192. Also see John Michael Archer (2005), Citizen Shakespeare: Freemen and Aliens in the Language of the Plays, New York: Palgrave Macmillan, pp. 146-150 and, for 'social compact,' Peter J. Leithard (2006), 'City of In-gratia: Roman Ingratitude in Shakespeare's Coriolanus,' Literature and Theology, 20, 349-351. For the most extensive treatment of inauthenticity and a plausible reading of Shakespeare's perspective on the forfeiture of agency in republican, representative government, consult Oliver M. Arnold (2005), The Third Citizen: Shakespeare's Theater and the Early Modern House of Commons, Baltimore: The Johns Hopkins University Press.

53. Compare Livy, Ab Urbe Condita 3.2 with Machiavelli, Discorsi 1.4, 1.

54. Shakespeare, Coriolanus 2.3, 220-222.

55. Shakespeare, Coriolanus 2.2, 256-257.

56. John Roe (2002), Shakespeare and Machiavelli, Woodbridge: Boydell and Brewer, p. 193. 
In Machiavelli's narrative, Rome's plebeians were ready to attack the recklessly candid Coriolanus; the tribunes save him from them. In Coriolanus, Shakespeare's tribunes, at first, call a crowd to 'bear him to th' rock Tarpeian and from thence unto destruction cast him. ${ }^{57}$ Reading Plutarch's account of the agitation that attended the creation of the Roman republic, Shakespeare was acquainted with 'seditious' tribunes. ${ }^{58}$ Furthermore, allegations of sedition were very much in the air in early modern England and in the minds of two of the realm's sovereigns. Elizabeth I silenced statesmen in the Lower House of Parliament claiming to represent the concerns of 'the commonality' in the late 1570 s and 1580 s, trying to legislate a further reform of the established church. Then and subsequently, the queen expressed her displeasure whenever her courtships became subjects for parliamentary debate. King James I was hostile to members of Parliament whose seemingly interminable debates were, in his estimation, stunts to avoid enacting what he most desired, a more perfect union between his two kingdoms, England and Scotland. But before we compare the tribunes' management of the electorate in Coriolanus with the representatives of 'The Commons,' we should be alert to the imperfect character of representation in Parliament. Local elites controlled the elections to the House of Commons. The possibilities for genuinely participatory regimes almost exclusively aired in debates about parishioners' prerogatives. So 'free consents' and 'free elections,' historian Oliver Arnold suggests, were phrases that seldom if ever could be applied to the Elizabethan and Jacobean parliamentary elections. Arnold may be correct ranking Shakespeare among political radicals determined to speak out about commoners' lack of voice. The playwright may well have expressed his displeasure in Coriolanus, suggesting that Rome's plebeians should 'never have traded in their rebellion for representation,' as Arnold indicates, but I think his simpler argument is more defensible - specifically, his judgment that Shakespeare's play displays its maker's fears that 'the representatives of the people might be oppressive masters rather than guardians of liberty.'59 On stage, this certainly is Coriolanus's reading of the commoners' masters and, I will suggest, it was prophetic.

But Machiavelli, for his part, was unworried about such potential popular usurpers. From what he learned about the Roman republic, he concluded that, in hundreds of elections during its hundreds of years, the citizens chose no more than four wicked tribunes or consuls. Shakespeare approached the problem of representation from a different angle. He found that Rome's tribunes wickedly manipulated the plebeians, who were too trusting and easily gulled; Mikail Hörnquist suggests that 'the Rome of [Shakespeare's] Coriolanus is an archaic state which still has a long way to go before becoming the perfect republic Machiavelli speaks of in the Discourses. ${ }^{60}$ His Coriolanus berates the senate for having ever set the city on that course. His mother scolds him for being 'too absolute,' for criticizing concessions, and for failing to

57. Shakespeare, Coriolanus 3.1, 212-213, 222, 265-269.

58. Plutarch's Life of Caius Martius Coriolanus was available to Shakespeare in Thomas North's translation. For 'the two seditious tribunes,' see his Lives of the Noble Grecians and Romanes, 2nd edn, London: Vautroullier and Wight, 1579, pp. 243-244.

59. Arnold, Third Citizen, pp. 187-192, 213-214.

60. Hörnquist, Machiavelli and Empire, p. 195. For Machiavelli's assessment (non fece quattro elezioni di che quello si avesse a pentire), see his Discorsi 1.58, 3. But also see McCormick, 'Controlling Elites,' p. 307, analysing another section of the Discorsi (1.48), which appears to acknowledge commoners' gullibility. Nobles present a slate of first-rate patricians and secondrate plebeians for commoners to consider. They select the former, 'confirm their virtue,' and 'do not see through the nomination strategy.' 
comprehend that 'policy' dictates compromises. His mentor Menenius agrees, adding that the protagonist's 'nature is too noble for this world. ${ }^{61}$ On both counts, nobility and intransigence, Coriolanus exhibited traits that we tend to associate with prophets disenchanted with the reigning rituals and routines of their time and place, because they failed to inspire virtue and justice. Prophets' disaffiliation means that they can never be at home in their homelands. Coriolanus comes to us dishonored, disaffected, and nearly throttled after the first three acts of Shakespeare's play, at which point, having been banished, he leaves Rome for 'a world elsewhere.' 62

He does not vanish from the stage. The final two acts have him in the company of his former enemies, the Volscians, leading them to the gates of Rome. But a delegation dissuades him from attacking. His mother, wife, and young son shame him for having turned on the city that turned on him. The tribunes wrongly and wickedly accuse him of ambition, and, although his actions during the final acts could be construed as corroboration, neither Shakespeare nor Plutarch would give Coriolanus's self-interest and ambition much play. ${ }^{63}$ But, plausibly, the playwright's ambition and irritation with commoners got stage time in Coriolanus. Historian Robert Ormsby imagines that dramatists who were also entrepreneurs may have been restless. The success of a play and the fate of a theater company could depend on audiences that were 'comprised of the socially and mentally unfit whose judgments,' if we may trust literature that was patently antitheatrical, were 'mutable and harmful.' Shakespeare's Coriolanus, in the first scene of the first act, echoes that estimate: 'with every minute you do change your mind and call him noble that was now your hate, him vile that was your garland.' Did the playwright rake into his character's contempt his own displeasure at having the whims of 'the vulgar sort' to some extent control his plays' reception and profit margin? ${ }^{64}$

Stephen Greenblatt usefully reminds us that Shakespeare, whose investments were nearly as dependent on the fickle, 'vulgar [or common] sort' as on early modern aristocratic patronage, was, unlike Machiavelli, a man whose leisure was gladly spent among commoners. Machiavelli once wrote "with disgust of the vulgar arguments and stupid games he was forced to watch' after he had been forcibly retired from the diplomatic

61. Shakespeare, Coriolanus 3.1, 254 ('too noble'); 3.2, 39 ('too absolute').

62. Shakespeare, Coriolanus 3.3, 135.

63. Compare Shakespeare, Coriolanus 1.1, 259-262 and 3.1, 80-81 with Plutarch, Lives, p. 261. Carson Holloway (2007), 'Shakespeare's Coriolanus and Aristotle's Great-Souled Man,' The Review of Politics, 69, 358-360, probes usefully for Coriolanus's motives, noting his 'ironical self-depreciation' and 'detachment from praise.' 'What, then, is Coriolanus's primary motivation,' Holloway inquires, answering that, 'animated by a kind of earnestness regarding nobility, or concern with virtue for its own sake,' Coriolanus 'calls to mind true magnanimity, which is more concerned with truth than with what people think.' Rummaging for the motives Shakespeare packs into his protagonist, Holloway probes usefully, but he is far from unique on that count. See Norman Rabkin's still valuable efforts to explain Coriolanus's 'absolute allegiance to his ideals' and to contrast it with others' 'temporizing,' for which see Rabkin (1966), 'Coriolanus: The Tragedy of Politics' Shakespeare Quarterly 17, 195-212, but also consult Patricia Meszaros's (1976) 'There is a World Elsewhere: Tragedy and History in Coriolanus,' Studies in English Literature, 16,280 , which seems to have implanted ambition in Coriolanus yet to have deprived him of political savvy: 'because "politics" does not exist for him,' she avers, 'he can recognize neither the need to assure his control of the state by accommodating himself to the expectations of the populace nor the need to handle Brutus and Sicinius with circumspection and outmaneuver them in their bid for power.'

64. Robert Ormsby (2008), 'Coriolanus, Antitheatricalism, and Audience Response,' Shakespeare Bulletin, 26, 46 and 51-52; for changeable plebeians (and, conceivably, playgoers), see Shakespeare, Coriolanus 1.1, 183-185. 
service and 'rusticated'; 'his only relief came in the evenings,' Greenblatt continues, drawing on the desolation expressed in one of Machiavelli's letters. At night, the Florentine would come alive in his library with 'his beloved authors,' Livy and others of that time. '[A]t last [Machiavelli] had companions fit for his intellect,' Greenblatt imaginatively yet, I think, correctly editorializes, adding - also correctly - that 'nothing could be further from Shakespeare's sensibility.' If the playwright ever 'showed signs of boredom at the small talk, trivial pursuits, and foolish games of ordinary people,' we do not know of it. ${ }^{65}$ Such observations and 'editorials' would seem to sabotage the interpretations on offer in this study, although one can envision Shakespeare's familiarity with pub culture breeding contempt for commoners who presumed to exercise political leverage and perhaps even more easily - see Machiavelli's purported 'disgust' with 'the vulgar' in rural Italy, leading him to romanticize citizens' participation in the early Roman republic. On these matters, however, we traffic in guesses rather than certainties.

But of one thing we can be sure. We know what some ordinary people, in Southwark, just outside the Globe Theater, were talking about when Shakespeare contemplated Coriolanus. Bits of evidence left by litigation tell us that, a few months before the play was first performed, 'common people and handicraftsmen' from the parish of St Saviour (now Southwark Cathedral) sued to have a say during their vestrymen's selection of churchwardens. Parishioners had asked Parliament to inquire why representatives from the congregation were systematically excluded from deliberations. ${ }^{66}$ Suits of this sort were rare. There are few traces of parishioner resistance elsewhere. ${ }^{67}$ But the resistance at St Saviour's is a matter of record and would have been hard for Shakespeare to have missed, even had he not set foot in the church, in which, at about that time (1607), he buried his brother Edmund. For theater financier Philip Henslowe, one of the playwright's competitors, and actor Edward Alleyn were members of the vestry, voting funds from 'the parish stock' to cover costs incurred in the struggle against 'the common people.' 68

Those parishioners-turned-plaintiffs may have played no part in Shakespeare's retrieval of republican Rome's plebeians. A vestry's insistence that popular participation in deliberations was 'unprofitable and inconvenient' may have had nothing to do with a somewhat similar view that Coriolanus expressed onstage. ${ }^{69}$ But, conceivably, both Shakespeare and the vestrymen at the parish church of St Saviour knew of the opinions expressed by Thomas Bilson, who, as the bishop of Winchester, had authority over the vestry and the precincts around the Globe Theater. Before the parishioners at St Saviour sued for 'voices' during deliberations, their bishop praised the earliest Christian church's authorities for having restrained commoners in their congregations from 'intermedl[ing]' with the selection of leaders. 'The rashenesse and rudenesse of the many [who] are often ledde rather with affection than with discretion' and their fondness for 'faction and flatterie' he maintained, disqualified them from having say or 'sway' in personnel or policy decisions. ${ }^{70}$ Bilson's reservations were anticipated.

65. Stephen Greenblatt (2004), Will in the World, New York: Norton, p. 389.

66. London Metropolitan Archives, Parish Records, 92/Sav/450, 404.

67. Julia F. Merritt (2005), The Social World of Early Modern Westminster: Abbey, Court, and Community, 1525-1640, Manchester: Manchester University Press, pp. 109-111.

68. London Metropolitan Archives, Parish Records, 92/Sav/450, 414.

69. John Stow (1720), A Survey of the Cities of London and Westminster, vol. 2, London: Churchill, et al., pp. 9-10.

70. Thomas Bilson (1593), The Perpetual Government of Christ's Church, London: Christopher Barker, pp. 358-361. 
'Factious practice,' Dudley Fenner claimed, could be prevented. Leaders could be trusted to channel commoners' concerns, and commoners could be trusted to realize that their corruptible reason had to be trained to make accurate assessments of the predicaments facing their congregations and their kingdom. ${ }^{71}$

Selfless, trusted leaders training and representing self-aware and discerning commoners: Shakespeare's Coriolanus could not imagine that scene. Machiavelli did. Can we, knowing what we know about the influence of faction and flattery? Researchers refer to 'motivated reasoning' to describe the ostensible suspension of political judgment that seems all too familiar as citizens fit their perceptions to partisanship. Discussions of the accuracy of information and the wisdom of policy are 'suffused with antagonistic meanings that transform utilitarian policymaking into occasions for symbolic status competition.' And this leads to what Dan Kahan calls a 'neutrality crisis.' Kahan writes about jurisprudence and judges' impartiality yet applies what he says about the latter to the 'cognitive illiberalism' of ordinary citizens - to the electorate. Its leaders polarize political conversation to retain the loyalties of followers who oblige by letting their leaders' self-interest determine their own. ${ }^{72}$ Coriolanus calls such commoners 'fragments,' as we know, and he decries their servility and changeability. ${ }^{73}$ As populist interpreters of the play say, the crowd onstage is not always subservient. Individuals venture a word or few, momentarily expressing an independent and generous judgment and challenging their tribunes to herd more effectively. But they do, and the fragments in Coriolanus inevitably fall back in line. Geoffrey Cohen reminds us that 'one of the most durable lessons in social psychology is the power of group influence,' and groups or factions award a decisive 'filtering role' to their partisan leaders. Ordinary citizens or commoners are led to think that they are forming opinions, but they are only choosing sides, or, to be precise, choosing the same side. Motivated reasoning is relentless. ${ }^{74}$

Machiavelli's people, protected by their tribunes, defined and asserted their interests, sustaining a tension between the elites and themselves, the populares, that safeguarded their republic. Shakespeare's prophet, Coriolanus, judges the people unfit, easily manipulated (or 'motivated'). Machiavelli trusted that, unlike elites, ordinary citizens would never let faction trump discretion. Shakespeare's Coriolanus - and, conceivably, Shakespeare himself - foresaw that they would. The early modern views just summarized are clearly at odds with each other, although by no means clear cut. Kahan and Cohen, whom we just left, for example, seemed to substantiate what might pass, albeit not without contestation, as a 'Shakespearean' mistrust in the independence as well as the intelligence of an electorate composed of ordinary citizens, but that mistrust is packed in the play alongside the playwright's criticisms of the plebeians' leaders, the tribunes, and their 'too noble' yet 'too absolute' critic, Coriolanus. Machiavelli's people and the tribunes are treated favorably, yet ferocious partisanship and conflict - rather than goodwill or enduring consensus - preserved their republics.

71. See Dudley Fenner (1585), Sacra Theologia Sive Veritas Quae est Secundum Pietatem, London: Dawson, fol. 121r; Fenner (1587), Defense of the Godly Ministers against the Slaunders of Dr. Bridges, Middelburg: Schilders, pp. 61-71; and Nicholas Bownde (1608), The Unbeleefe of St Thomas the Apostle, Cambridge: Legge, pp. 60-67.

72. Dan M. Kahan (2011), 'Neutral Principles, Motivated Cognition, and Some Problems for Constitutional Law,' Harvard Law Review, 125, 1-30.

73. Shakespeare, Coriolanus 1.1, 223.

74. Geoffrey L. Cohen (2003), 'Party Over Policy: The Dominating Impact of Group Influence on Political Beliefs,' Journal of Personality and Social Psychology, 85, 808-822. 
Here, Shakespeare and Machiavelli have been introduced as proponents of competing visions of the virtues and political liabilities associated with citizens' deference and defiance. What they advocated, as they repossessed Coriolanus - and the crisis his candor and contempt precipitated - affords us an occasion not only to contextualize two influential reappropriations or reinventions of early republican Rome but also to reflect on the challenges posed to leadership and to leadership studies by the development of participatory regimes. 